Florida State University College of Law

Scholarship Repository

Scholarly Publications

Fall 2009

\title{
Reasonableness as a Rule: A Paean to Justice O'Connor's Dissent in Atwater v. City of Lago Vista
}

Wayne A. Logan

Florida State University College of Law

Follow this and additional works at: https://ir.law.fsu.edu/articles

Part of the Constitutional Law Commons, Criminal Law Commons, and the Fourth Amendment Commons

\section{Recommended Citation}

Wayne A. Logan, Reasonableness as a Rule: A Paean to Justice O'Connor's Dissent in Atwater v. City of Lago Vista, 79 MISs. L.J. 115 (2009),

Available at: https://ir.law.fsu.edu/articles/178

This Article is brought to you for free and open access by Scholarship Repository. It has been accepted for inclusion in Scholarly Publications by an authorized administrator of Scholarship Repository. For more information, please contact efarrell@law.fsu.edu. 


\title{
REASONABLENESS AS A RULE: A PAEAN TO JUSTICE O'CONNOR'S DISSENT IN ATWATER V. CITY OF LAGO VISTA
}

\author{
Wayne A. Logan *
}

When invited to participate in this symposium, and asked to identify a particular dissent from the Supreme Court's Fourth Amendment caselaw to focus upon, many candidates came to mind. The dissents of Justices Douglas in Terry $v$. Ohio $^{1}$ and Brandeis in Olmstead v. United States ${ }^{2}$ had strong immediate appeal, and indeed are ably addressed by other symposium contributors. ${ }^{3}$ I wished, however, to consider a dissent of more recent vintage-yet one having similar foundational force relative to Fourth Amendment principles and significant impact on policing and civil liberties. With these criteria in mind, I soon settled upon my dissent of choice: that of Justice Sandra Day O'Connor in Atwater v. City of Lago Vista. ${ }^{4}$

Atwater, the "soccer mom" case as it has come to be known, answered a basic question long left unresolved by the Court:

- Gary and Sallyn Pajcic Professor of Law and Associate Dean for Academic Affairs, Florida State University College of Law. The Article is based on remarks offered at the "Great Fourth Amendment Dissents" symposium hosted by the University of Mississippi School of Law and cosponsored by the National Center for Justice and the Rule of Law and the National Judicial College, February 12-13, 2009. I thank Professor Thomas Clancy for his warm hospitality during the symposium and Christopher Ewbank (J.D. '09) and Andrew Grogan (J.D. '10) for their excellent research assistance.

' 392 U.S. 1, 35 (1968) (Douglas, J., dissenting).

2277 U.S. 438, 471 (1928) (Brandeis, J., dissenting).

3 See Carol Steiker, Brandeis in Olmstead: "Our Government is the Potent, Omnipresent Teacher", 79 MISS. L.J. 147 (2009); Paul Butler, "A Long Step Down the Totalitarian Path": Justice Douglas's Great Dissent in Terry v. Ohio, 79 Miss. L.J. 9 (2009). The question of what qualifies as a great dissent has inspired considerable interest of late. See I Dissent: GREat OpPosing Opinions in Landmark Supreme CourT Cases (Mark Tushnet ed., 2008); William J. Brennan, In Defense of Dissents, 37 HaSTINGS L.J. 427 (1986); Robert G. Flanders, The Utility of Separate Judicial Opinions in Appellate Courts of Last Resort: Why Dissents are Valuable, 4 ROGER WILliaMs U. L. REV. 401 (1999); Lani Guinier, Foreword: Demosprudence Through Dissent, 122 HARV. L. REV. 4 (2008); Allison O. Larsen, Perpetual Dissents, 15 Geo. MASON L. Rev. 447 (2008); Randall T. Shepard, What Can Dissents Teach Us?, 68 ALB. L. Rev. 337 (2005).

4 532 U.S. 318 (2001). 
whether a warrantless arrest for a minor offense violates the reasonableness clause of the Fourth Amendment, the Amendment's "touchstone." In her dissent, joined by Justices Stevens, Ginsburg, and Breyer, Justice O'Connor condemned the majority's approval of a motorist's custodial arrest for failure to wear a seatbelt, punishable under Texas law only by a modest fine. ${ }^{6}$ The outcome, O'Connor fairly concluded, afforded police "constitutional carte blanche to effect an arrest whenever there is probable cause to believe a fine-only misdemeanor has been committed," an outcome "irreconcilable with the Fourth Amendment's command that seizures be reasonable." While conceding the administrative appeal of providing police the unqualified right to arrest for any and all offenses, Justice O'Connor asserted that such appeal "by no means trumps the values of liberty and privacy at the heart of the Amendment's protections." Administrative ease, O'Connor insisted, falls "far short of rationalizing the extraordinary intrusion on Gail Atwater and her children."

The majority's decision to equate probable cause with reasonableness had two major ramifications, according to Justice O'Connor. First, with probable cause now serving as both a necessary and sufficient basis for arrest, police were free to invoke their arrest power for a myriad of minor offenses, having major impact on the "everyday lives of Americans."10 Second, with broadened warrantless arrest authority comes an "arsenal" of police powers, including the power to search cars and drivers and inventory the contents of their vehicles. ${ }^{11}$ The "unbounded discretion" afforded police to execute arrests and exercise such powers, Justice O'Connor reasoned, carried a "grave potential for abuse." ${ }^{\prime 2}$

\footnotetext{
s Samson v. California, 547 U.S. 843, 855 n.4 (2006).

- Atwater, 532 U.S. at 360 (O'Connor, J., dissenting).

7 Id. at 366 .

${ }^{8}$ Id.

Id. at $371,373$.

10 Id. at 371 .

1 Id. at 372

12 Id.
} 
In the space available here, I will seek to make the case that Justice O'Connor's Atwater dissent, wise when offered almost a decade ago, and prescient in light of subsequent events, is deserving of a place in the pantheon of the Court's great Fourth Amendment dissents.

\section{ATWATER AND THE DEMISE OF REASONABLENESS}

In March 1997, Gail Atwater was returning home after retrieving her two children (a boy and girl, ages three and five) from soccer practice. ${ }^{13}$ She slowly cruised her neighborhood street in the small community of Lago Vista, Texas, driving the family pickup truck at fifteen miles per hour, in the hope of finding a cherished toy her son had dropped from the vehicle. ${ }^{14}$ Police officer Barton Turek observed Atwater, together with her children in the front seat, and noticed that neither Atwater nor her children were wearing seat belts-in violation of Texas statutory law. ${ }^{15}$ After detaining Atwater at the side of the road, Turek told her, "We've met before," referring to a prior incident when Turek mistakenly thought Atwater's son was not wearing a seat belt. ${ }^{16}$ He then "yell[ed]" that Atwater was "going to jail"17 and rejected her request to take the children to a friend's home nearby, despite the fact that they were "frightened, upset, and

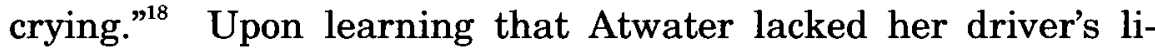
cense and insurance documentation because her purse had been stolen, a story he had "heard . . . two-hundred times," handcuffed Atwater and transported her to the police station (ironically enough, without first attaching her seat belt). ${ }^{20}$ Upon

${ }^{13}$ See Ross E. Milloy, Public Lives: For Seat-Belt Violator, a Jam, a Jail and Unmoved Justices, N.Y. TIMES, Apr. 28, 2001, at A9.

${ }^{14}$ Id.

${ }^{15}$ Atwater, 532 U.S. at 323-24.

I6 Id. at 324 (citation omitted).

17 Id.

18 Id. Alerted by the commotion, a friend eventually arrived and prevented the children from being taken away by Turek, as he had threatened. Id. at 368-69 (O'Connor, J., dissenting).

19 Id. at 324 (majority opinion) (citation omitted).

2o Id. at 369 (O'Connor, J., dissenting) (citation omitted). A subsequent inventory of Atwater's truck revealed two tricycles, a bicycle, a cooler, a bag of charcoal, toys, groce- 
arriving at the police station, Atwater was stripped of her personal possessions, subjected to a "mug shot," and placed in a booking cell for approximately one hour before she was brought before a magistrate and released on a $\$ 310$ bond. $^{21}$ Atwater eventually pled no contest to the seat belt violation and paid a $\$ 50$ fine. ${ }^{22}$

After city officials rebuffed her request that police receive better training and closer supervision, Atwater filed a civil rights suit under 42 U.S.C. $\$ 1983$, alleging the warrantless arrest for the fine-only seatbelt violation constituted an unreasonable seizure under the Fourth Amendment. ${ }^{23}$ The trial court entered summary judgment in favor of the defendants, and a panel of the Fifth Circuit reversed. ${ }^{24}$ On rehearing en banc, the Fifth Circuit again reversed. ${ }^{25}$ The Supreme Court granted certiorari, agreeing to address whether "the Fourth Amendment, either by incorporating common-law restrictions on misdemeanor arrests or otherwise, limits police officers' authority to arrest without warrant for minor criminal offenses." ${ }^{26}$

By a five-four vote, the Court affirmed. ${ }^{27}$ Justice Souter's opinion for the majority first examined early common law and framing era authorities on police power to execute warrantless arrests for offenses not involving a "breach of the peace." 28 The upshot of this history, he wrote, is that "the common-law commentators (as well as the sparsely reported cases) reached divergent conclusions" on such police authority. ${ }^{29}$

Justice Souter noted that while several "eminent authorities" supported the view that framing era warrantless arrest

ries, and two pairs of children's shoes. See Linda Greenhouse, Divided Justices Back Full Arrests on Minor Charges, N.Y. TIMES, Apr. 25, 2001, at A1.

${ }_{21}$ Atwater, 532 U.S. at 324 (majority opinion).

${ }_{22}$ Id. Atwater's other charges, driving without a license and failing to provide proof of insurance, were dismissed. Id. In addition to the fine, Atwater paid $\$ 110$ to retrieve her truck from the police impoundment lot. See Editorial, An Erosion of Rights, SaLT LAKE TRIB., Apr. 30, 2001, at A10 (on file with author).

23. See Milloy, supra note 13.

21 Atwater v. City of Lago Vista, 165 F.3d 380 (5th Cir. 1999).

${ }^{25}$ Atwater v. City of Lago Vista, 195 F.3d 242 (5th Cir. 1999) (en banc).

${ }_{26}$ Atwater, 532 U.S. at 326.

27. at 322 .

29 Id. at 327.

2 Id. at 328 \& n.2. 
power was quite limited, the record was insufficient to support a conclusion that Atwater's arrest violated the Fourth Amendment. ${ }^{30}$ In particular, Justice Souter noted a 1631 English case upholding a warrantless arrest for dice play, later cited by several eighteenth-century commentators for the proposition that nonfelony arrest authority was not limited to breaches of the peace. $^{31}$ Early statutes, he explained, further undermined the view that officers were categorically barred from executing arrests for non-breach-of-the-peace misdemeanors. ${ }^{32}$

Justice Souter next evaluated whether subsequent authority or practice clarified the warrantless arrest authority of officers. On this count, he concluded, "the historical record as it has unfolded since the framing" showed an increasing receptiveness to warrantless arrests for non-breach-of-the-peace misdemeanors. ${ }^{33}$ In support, Justice Souter quoted Michigan Law Professor Horace Wilgus, who observed in 1924:

The states may, by statute, enlarge the common law right to arrest without a warrant, and have quite generally done so or authorized municipalities to do so, as for example, an officer may be authorized by statute or ordinance to arrest without a warrant for various misdemeanors and violations of ordinances, other than breaches of the peace, if committed in his presence. $^{34}$

In the ensuing decades, Justice Souter observed, interest in broadened police arrest power continued largely unabated, such that by 2001 statutes in every American jurisdiction permitted officers some degree of warrantless arrest authority for non breach-of-the-peace misdemeanors. ${ }^{35}$ As a result, Atwater's was "simply ... not a case in which the claimant can point to 'a clear

Id. at 329 .

31 Id. at 331 (citing Holyday v. Oxenbridge, (1631) 79 Eng. Rep. 805 (K.B.)).

$32 \quad I d$. at 337 (noting, in particular, early English statutes permitting warrantless arrests of persons roaming the streets at night ("night-walkers")). The Court also noted statutes from the eighteenth century and before that targeted gamblers, peddlers, vagrants, and “negligent carriage drivers." Id. at 335.

${ }^{33}$ Id. at 340-45.

${ }^{34}$ Id. at 343 (quoting Horace L. Wilgus, Arrest Without a Warrant, 22 MICH. L. REv. $541,550 \&$ n.54 (1924)).

${ }_{35}$ Id. at $344-45,355$ app. 
answer [that] existed in 1791 and has been generally adhered to by the traditions of our society ever since."”36 The Court therefore was obliged to "strike a current balance between individual and societal interests."37

To the Atwater majority, this balance weighed in favor of adopting a rule that, rather than turning on "sensitive, case-bycase determinations," could be easily and readily applied by police $^{38}$ The majority rejected Atwater's suggestion that police arrest authority depend on whether (1) the underlying offense carried the threat of jail time or (2) it was "necessary for enforcement of the traffic laws," or to halt "[an] offense [that] would otherwise continue and pose a danger to others on the road. ${ }^{39}$ Tying arrest authority to the gravity of the suspected offense was untenable because it would require difficult on-thescene judgments about whether jail time was legally authorized. ${ }^{40}$ Likewise, making the authority contingent on scofflaw or otherwise dangerous offenders was problematic. ${ }^{41}$ Citing speeding as one possible problem area, Justice Souter asked, "[I]s it not fair to expect that the chronic speeder will speed again despite a citation in his pocket . . ?" ${ }^{{ }^{12}}$ Requiring police to divine whether behavior would persist would put them in an

Id. at 345 (alteration in original) (quoting County of Riverside v. McLaughlin, 500 U.S. 44, 60 (1991) (Scalia, J., dissenting)).

${ }^{37}$ Id. at 346 (citing Wyoming v. Houghton, 526 U.S. 295, 299-300 (1999) and Vernonia Sch. Dist. 47J v. Acton, 515 U.S. 646, 652-53 (1995)).

${ }_{38}$ In language echoing other recent opinions of the Court endorsing similar brightline rules, Justice Souter characterized the need as follows:

Often enough, the Fourth Amendment has to be applied on the spur (and in the heat) of the moment, and the object in implementing its command of reasonableness is to draw standards sufficiently clear and simple to be applied with a fair prospect of surviving judicial second-guessing months and years after an arrest or search is made. Courts attempting to strike a reasonable Fourth Amendment balance thus credit the government's side with an essential interest in readily administrable rules.

Id. at 347 .

Id. at 347,349 (quoting Brief of Petitioners at 46, Atwater v. City of Lago Vista, 532 U.S 318 (2001) (No. 99-1408), 2000 WL 1299527).

${ }^{40}$ Id. at 348-49. Justice Souter elaborated: "It is not merely that we cannot expect every police officer to know the details of frequently complex penalty schemes, . . but that the penalties for ostensibly identical conduct can vary on account of facts difficult (if not impossible) to know at the scene of arrest." Id. (internal citations omitted).

${ }^{41} \quad I d$. at 349.

42 Id. 
"almost impossible spot," and "guarantee increased litigation over many of the arrests that would occur., ${ }^{, 43}$ In the end, Justice Souter concluded that having the constitutionality of an arrest hinge on such vicissitudes would create among police a "systemic disincentive to arrest":

An officer not quite sure that the drugs weighed enough to warrant jail time or not quite certain about a suspect's risk of flight would not arrest, even though it could perfectly well turn out that, in fact, the offense called for incarceration and the defendant was long gone on the day of the trial. Multiplied many times over, the costs to society of such underenforcement could easily outweigh the costs to defendants of being needlessly arrested and booked. ${ }^{44}$

Finally, Justice Souter questioned whether warrantless misdemeanor arrests ultimately "need constitutional attention. ${ }^{35}$ For one thing, he reasoned, the Court's prior decisions establish that a magistrate must review all warrantless arrests within forty-eight hours to ensure that probable cause supports the detention. ${ }^{46}$ Constitutional protection is also afforded, on a case-by-case basis, to guard against any arrest (whether felony or misdemeanor) that is "conducted in an extraordinary manner, unusually harmful to [the citizen's] privacy or even physical interests. ${ }^{, 47}$ Furthermore, legislatures in several jurisdictions had expressly limited police authority to execute warrantless arrests for minor offenses, an alternative Justice Souter deemed preferable to a broad constitutional rule. ${ }^{48}$ Statutory limits were

43. at 350. Justice Souter added:

It is no answer that the police routinely make judgments on grounds like risk of immediate repetition; they surely do and should. But there is a world of difference between making that judgment in choosing between the discretionary leniency of a summons in place of a clearly lawful arrest, and making the same judgment when the question is the lawfulness of the warrantless arrest itself.

Id.

${ }^{44}$. at 351 .

${ }^{45}$ Id. at $351-52$.

46 Id at 352 (citing County of Riverside v. McLaughlin, 500 U.S. 44, 55-58 (1991)).

${ }^{47} I d$. at 353 (quoting Whren v. United States, 517 U.S. 806, 818 (1996)).

48 Id. at 352. Justice Souter offered that such an approach is preferable because "the statute can let the arrest power turn on any sort of practical consideration without having to subsume it under a broader principle." Id. 
"natural" because it is in the interest of law enforcement "to limit petty-offense arrests, which carry costs that are simply too great to incur without good reason. ${ }^{\star 49}$

Justice Souter concluded by expressing confidence that such statutory limits, "combined with the good sense (and, failing that, the political accountability) of most local lawmakers and law-enforcement officials," provided sufficient protection to citizens. $^{50}$ Indeed, the protection itself accounted for a "dearth of horribles demanding redress" in the form of "foolish, warrantless misdemeanor arrests." ${ }^{51}$ While acknowledging that such arrests likely occurred on occasion, Justice Souter expressed confidence that "surely the country is not confronting anything like an epidemic of unnecessary minor-offense arrests. ${ }^{, 52}$ Moreover, any concern that police might utilize their expansive authority to arrest, in lieu of citation, and thereby arbitrarily harass citizens, was "speculative" insofar as the record failed to indicate that such a potential "has ever ripened into a reality.

In sum, the Court rejected Atwater's claim that her warrantless arrest and detention for a fine-only offense, as permitted by Texas statutory law ${ }^{54}$ violated the Fourth Amendment. The end result of Atwater is that "[i]f an officer has probable cause to believe that an individual has committed even a very minor criminal offense in his presence, he may, without violating the Fourth Amendment, arrest the offender." ${ }^{355}$ The sole limit is that the act of physical arrest itself cannot be carried out in an "extraordinary manner, unusually harmful to [the citizen's] privacy or ... physical interests. ${ }^{956}$

${ }^{49} I d$.

so Id. at 353 .

${ }^{5}$ Id.

${ }^{52}$ Id.

${ }^{53}$ Id. at 354 \& $\mathrm{n} .25$.

${ }^{54}$ See TEX. Code Crim. Proc. ANN. art. 14.01(b) (Vernon 2005) (providing that a "peace officer may arrest an offender without a warrant for any offense committed in his presence or within his view"); TEX. TRANSP. CODE ANN. $\$ 543.001$ (Vernon 1999) (providing that a "peace officer may arrest without a warrant a person found committing a violation").

${ }_{s s}$ Atwater, 532 U.S. at 354.

${ }^{56}$ Id. (quoting Whren v. United States, 517 U.S. 806, 818 (1996)). 
Dissenting, Justice O'Connor, joined by Justices Ginsburg, Breyer, and Stevens, criticized the majority for affording "constitutional carte blanche" to officers to arrest for any offense, no matter how insignificant, solely on the basis of probable cause. ${ }^{57}$ Justice O'Connor noted that the common law and historical record on minor-offense warrantless arrest authority was somewhat ambiguous ${ }^{58}$ but emphasized that prior statements by members of the Court gainsaid such authority. ${ }^{59}$ Moreover, while the Court twenty-five years before in Watson $v$. United States had held that public warrantless arrests for felonies were justified solely on the basis of probable cause, there the historical record was far clearer and the state interest in immediate arrest far greater. ${ }^{60}$ Finally, while the Court's 1996 decision in Whren $v$. United States approved of probable cause-based warrantless stops of motorists regardless of the subjective (perhaps pretextual) motivation of police, Atwater had been subject to a full custodial arrest. ${ }^{61}$ "Justifying a full [custodial] arrest by the same quantum of evidence that justifies a traffic stop- even though the offender cannot ultimately be imprisoned for her conduct - defies any sense of proportionality and is in serious

${ }^{57}$ Id. at 366 (O'Connor, J., dissenting).

${ }^{58}$ Id. at 362-63 (stating that the "Court's thorough exegesis makes it abundantly clear that warrantless misdemeanor arrests were not the subject of a clear and consistently applied rule at common law"). To scholars, most notably Professor Tom Davies, the framing era record is not so ambiguous, quite clearly evincing the limited warrantless arrest authority of law enforcement. See Thomas Y. Davies, The Fictional Character of Law-and-Order Originalism: A Case Study of the Distortions and Evasions of Framing-Era Arrest Doctrine in Atwater v. Lago Vista, 37 WAKE FOREST L. REV. 239 (2002).

${ }^{59}$ Atwater, 532 U.S. at 362 (O'Connor, J., dissenting) (citing Gustafson v. Florida, 414 U.S. 260, 266-67 (1973) (Stewart, J., concurring)); United States v. Robinson, 414 U.S. 218, 238 n.2 (1973) (Powell, J., concurring)). The majority's exclusive probable cause-based standard also conflicted with several of the Court's prior decisions linking the reasonableness of police seizures to the gravity of the offense involved. See, e.g., Illinois v. McArthur, 531 U.S. 326, 336 (2001) (upholding seizure of resident because offense was "jailable"); Welsh v. Wisconsin, 466 U.S. 740, 754 (1984) (invalidating inhome warrantless arrest because offense was "nonjailable").

${ }_{\infty}$ Atwater, 532 U.S. at 362 (O'Connor, J., dissenting) (citing Watson v. United States, 423 U.S. $411(1976)$ ).

61 Id. at 363 (noting that "[t]here are significant qualitative differences between a traffic stop and a full custodial arrest."). 
tension with the Fourth Amendment's proscription of unreasonable seizures. ${ }^{\text {"62 }}$

Given the perceived ambiguous nature of the historical and precedential record, Justice O'Connor then engaged in balancing analysis, much like the majority. Rather than deferring to the avowed administrative benefits of a bright-line rule in evaluating reasonableness, however, Justice O'Connor expressed alarm over the ramifications of affording police unfettered discretionary authority to arrest for minor offenses. She first catalogued the major personal consequences of custodial arrests, including detention in a holding facility for up to forty-eight hours without judicial certification that the arrest was supported by probable cause; ${ }^{63}$ the embarrassment and potential danger attending detention; ${ }^{64}$ and the social stigma associated with having an arrest record. ${ }^{65}$ She then highlighted the range of critically important investigatory powers tied to the occurrence of lawful arrests, such as the automatic right to search of the body and possessions of arrestees, ${ }^{66}$ and the passenger compartment and any containers therein if the arrestee is driving a car. $^{67}$

In order to justify such a "severe intrusion on an individual's liberty," Justice O'Connor reasoned, the governmental need must be substantial. ${ }^{68}$ However, in the context of fine-only offenses, this need was manifestly modest and sufficiently served by the less onerous alternative of a citation. Given the availability of citations, Justice O'Connor reasoned, it betrayed reasonableness to endorse a bright-line rule that "deems a full custodial arrest to be reasonable in every circumstance" solely because the officer had probable cause to believe that a violation occurred. ${ }^{69}$ Such an approach defied the Fourth Amendment

\footnotetext{
${ }^{62}$ Id. at 364 .

6s Id. (citing County of Riverside v. McLaughlin, 500 U.S. 44 (1991)).

${ }^{64}$ Id. (citing Rosazza \& Cook, Jail Intake: Managing a Critical Function-Part One: Resources, 13 AM. JAILS 35 (Mar./Apr. 1999)).

${ }^{65}$ Atwater, 532 U.S. at 364-65 (O'Connor, J., dissenting) (citing Paul v. Davis, 424 U.S. 693 (1976)).

${ }^{66}$ Id. at 364 (citing United States v. Robinson, 414 U.S. 218 (1973)).

${ }^{67}$ Id. (citing New York v. Belton, 453 U.S. 454 (1981)).

${ }^{6} I d$. at 365 .

${ }^{\infty}$ Id.
} 
requirement that a police action be a "reasonable and proportional response to the circumstances of the offense," instead giving police "unfettered discretion" to execute custodial arrests "without articulating a single reason why such action is appropriate." ${ }^{70}$

In place of the majority's bright-line rule, Justice O'Connor advocated a case-by-case constitutional analysis modeled on Terry v. Ohio: when an officer has probable cause to believe that a fine-only offense has been committed, the officer "should issue a citation unless the officer is 'able to point to specific and articulable facts which, taken together with rational inferences from those facts, reasonably warrant [the additional] intrusion' of a full custodial arrest." ${ }^{\prime 1}$ To Justice O'Connor, such a rule would be only modestly less clear and bright than that imposed by the majority, in that it would merely require "a legitimate reason for the decision to escalate the seizure into a full scale custodial arrest." ${ }^{\prime 2}$ Furthermore, whatever the option lacked in categorical quality and administrability, it compensated for "in fidelity to the Fourth Amendment's command of reasonableness and sensitivity to the competing values protected by that Amendment." ${ }^{, 73}$ As for the majority's concern over purported "systematic disincentives" associated with potential civil rights actions for false arrest, Justice O'Connor observed that qualified immunity largely served to insulate against the threat of actionable civil rights claims, and, at any rate, to the extent arrest disincentives were operative, they did not free the Court to "ignore the central [reasonableness] command of the Fourth Amendment." ${ }^{74}$

Applying her Terry-based test, Justice O'Connor concluded that neither "law nor reason" supported Turek's decision to arrest Atwater. ${ }^{75}$ Atwater, a mother of two who had lived in the area for sixteen years, and whose only previous violationfailing to signal a lane change while driving-occurred ten years

${ }^{70}$ Atwater, 532 U.S. at 372 (O'Connor, J., dissenting).

${ }^{71}$ Id. at 366 (alteration in original) (quoting Terry v. Ohio, 392 U.S. 1, 21 (1968)).

Id.

${ }^{73}$ Id.

74 Id. at 368 .

${ }^{75}$ Id. 
earlier, immediately accepted responsibility and apologized to Turek for her misbehavior. ${ }^{76}$ It was thus likely that she thereafter would have complied with the seat belt law, and be available for a court appearance if necessary, making a citation a tenable and less restrictive option. ${ }^{77}$ Justice O'Conner further noted that custodial arrest also failed to serve the interests of Atwater's two young children. ${ }^{78}$ Turek's decision to arrest Atwater traumatized the children, leaving them distraught and fearful of police. ${ }^{79}$ Instead of serving as a lesson in legal responsibility, as would be achieved by a citation, the arrest "taught the children an entirely different lesson: that the bad person could just as easily be the policeman as it could be the most horrible person they could imagine., ${ }^{800}$ Justice O'Connor added that Turek's actions were "disproportionate" to Atwater's wrongdoing and that “ $[t]$ he majority's assessment that 'Atwater's claim to live free of pointless indignity and confinement clearly outweighs anything the City can raise against it specific to her case,' is quite correct. In my view, the Fourth Amendment inquiry ends there." ${ }^{\text {s1 }}$

Finally, Justice O'Connor turned her sights to the broader implications of the majority's bright-line rule. While governments surely should be free to enact public welfare-related laws punishable only by fine, ${ }^{82}$ providing police categorical authority to arrest for their violation carried "grave potential for abuse," particularly because the Court's prior decision in Whren v. United States rendered constitutionally irrelevant the subjective motivations of police. ${ }^{83}$ "After [the majority's decision]," O'Connor observed, "the arsenal available to any officer extends to a full arrest and the searches permissible concomitant to that arrest." ${ }^{\$ 4}$ To Justice O'Connor, precisely because the subjective motivations of police cannot now be considered, the Court must

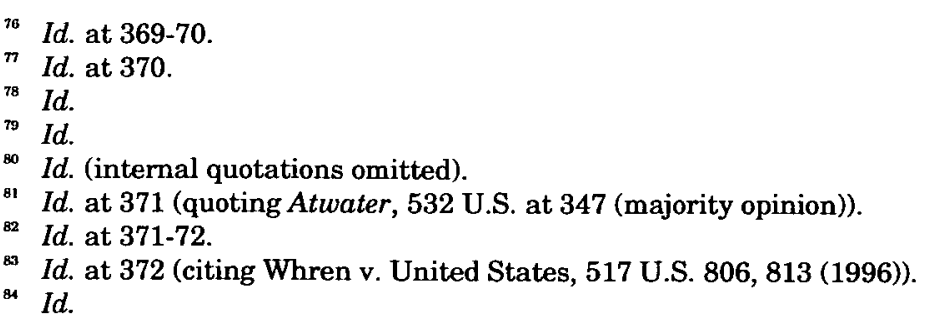


"vigilantly ensure" that police behaviors-"which are properly within our reach-comport with the Fourth Amendment's guarantee of reasonableness. ${ }^{" 85}$

\section{THE “EPIDEMIC"}

Before considering the jurisprudential and practical effects of Atwater, it is important to discuss two empirical matters that undergird the majority's decision and were rightly disputed by Justice O'Connor. First, the majority downplayed the need for constitutional regulation of warrantless arrest authority out of a belief that police naturally lack incentive to arrest for minor violations because they "carry costs too great to incur without good reason. ${ }^{, 86}$ As Justice O'Connor suggested, however, the majority's sense of police motivation was at best naïve. ${ }^{87} \mathrm{Be}-$ cause arrests serve as triggering events justifying an array of attendant police powers, most notably searches incident to arrest,${ }^{88}$ police have strong incentive to arrest for minor offenses in the hope of securing evidence of more serious crimes (typically, illegal drug or weapon possession).

Second, the majority insisted that constitutional oversight was not needed because the nation was "not confronting anything like an epidemic of unnecessary minor-offense arrests.." ${ }^{\prime 9}$ In support, the majority pointed out that Atwater's counsel at oral argument was able to identify only one other instance "of comparably foolish, warrantless misdemeanor arrests, ${ }^{\prime \prime 0}$ serving to confirm that "there simply is no evidence of widespread abuse of minor-offense arrest authority," and that counsel's posited "potential for abuse" had not "ripened into a reality."

Again, Justice O'Connor justly disputed the majority's assertions. As a threshold matter, she questioned the majority's fixation on the purported "relatively small number of published

\footnotetext{
${ }^{85} I d$.

26 Id. at 321 (majority opinion).

${ }^{87}$ Id. at 372 (O'Connor, J., dissenting).

Atwater, 532 U.S. at 353 (majority opinion).

89 Id.

$\infty \quad I d$.

${ }^{91}$ Id. at 372 (O'Connor, J., dissenting).
} 
cases," noting that it "proves little and should provide little solace. ${ }^{92}$ It has long been known that paucity of published (and for that matter unpublished) case law is a poor barometer of the actual existence of events. ${ }^{93}$ This is perhaps especially so with street-level searches and seizures based on minor offenses, a context particularly conducive to "invisible" practices, ${ }^{94}$ due to the effort and expense associated with constitutional litigation ${ }^{95}$ and the natural disincentive to pursue a claim when no longterm deprivation of liberty is at stake. ${ }^{96}$ Moreover, minoroffense arrest data, as noted by Atwater's counsel in an unsuccessful petition for rehearing, very likely significantly understate the frequency of such arrests, for two chief reasons. ${ }^{97}$ First, minor offense arrests are often not recorded as such if a search, conditioned upon the arrest, resulted in discovery of contraband or evidence of a more serious crime..$^{98}$ Second, the data fail to reflect instances when police "unarrest" individuals-that is,

${ }^{92} I d$.

${ }_{93}$ Id. For an early yet still apt recognition of this, see Brinegar v. United States, 338 U.S. 160, 181 (1949) (Jackson, J., dissenting) (noting that "invasion of the personal liberty of the innocent too often finds no practical redress," and that "[t]here may be, and I am convinced that there are, many unlawful searches . . . of innocent people which turn up nothing incriminating...”). See also, e.g., Rawlings v. Kentucky, 448 U.S. 98, 121 (1980) (Marshall, J., dissenting) ("Because we are called on to decide whether evidence should be excluded only when a search has been 'successful,' it is easy to forget that the standards we announce determine what government conduct is reasonable in searches and seizures directed at persons who turn out to be innocent as well as those who are guilty. I continue to believe that ungrudging application of the Fourth Amendment is indispensable to preserving the liberties of a democratic society.").

34 See, e.g., Caleb Foote, Law and Police Practice: Safeguards in the Law of Arrest, 52 Nw. U. L. REv. 16, 20-21 (1957); Jerome Hall, The Law of Arrest in Relation to Contemporary Social Problems, 3 U. CHI. L. REV. 345, 359-62 (1936).

${ }_{96}$ Gail Atwater qualified as a notable exception in this regard. She sued solely to vindicate what she saw as her Fourth Amendment right, not to suppress evidence uncovered by police in a search incident to arrest. Atwater and her husband, a physician, sold their home and incurred legal costs in excess of $\$ 100,000$. Atwater told one reporter: "If someone like me, a soccer mom, can be humiliated and handcuffed in front of her children, what happens to the poor migrant worker or minority when they're stopped?" Milloy, supra note 13, at A9.

${ }^{\infty}$ See Brinegar v. United States, 338 U.S. 160, 181 (1949) (Jackson, J., dissenting) (noting that "invasion of the personal liberty of the innocent too often finds no practical redress. There may be, and I am convinced that there are, many unlawful searches ... of innocent people which turn up nothing incriminating ....").

$n$ Petition for Rehearing at 4-5, Atwater, 532 U.S. 318 (No. 99-1408) (providing data on traffic-related arrests in several states).

${ }^{3}$ Id. 
police conduct a search ostensibly based on an arrest for a minor offense, find no evidence or contraband resulting in a more serious prosecution, and release an individual with a mere citation or warning. ${ }^{99}$

In any event, even if one were to accept the majority's curious notion that a constitutional violation is acceptable merely because it rarely occurs, ${ }^{100}$ the majority's empirical premise was clearly incorrect. Ample evidence existed at the time of Atwater of a profusion of "very minor offense" arrests, triggering incident searches resulting in more serious criminal prosecutions. For instance, state and lower federal courts condoned warrantless arrests, and searches incident thereto, for myriad minor auto and non-auto-related offenses, including:

illegal parking: ${ }^{101}$ littering; ${ }^{102}$ riding a bicycle on a sidewalk ${ }^{103}$ or without a headlight; ${ }^{104}$ civil contempt (based on a civil bench warrant); ${ }^{105}$ juvenile curfew violation $;{ }^{106}$ truancy $;{ }^{107}$ speeding; ${ }^{108}$ driving with a broken taillight; ${ }^{109}$ possessing drug paraphernalia; ${ }^{110}$ violating an alcohol open container law; ${ }^{111}$ public drinking; ${ }^{112}$ underage possession of alcohol; ${ }^{113}$ "pedestrian interfe-

99 Id.

100 Indeed, the rarity of minor offense arrests, if accurate, itself can be said to heighten their Fourth Amendment unreasonableness. Cf. Coker v. Georgia, 433 U.S. 584, 596-97 (1977) (citing paucity of jury death verdicts imposed on defendants convicted of rape as evidence supporting the view that the death penalty in such situations violates the Eighth Amendment).

${ }_{101}$ Williams v. State, 726 S.W.2d 99 (Tex. Crim. App. 1986).

${ }_{102}$ United States v. Herring, 35 F. Supp. 2 d 1253 (D. Or. 1999); State v. Sparks, 422 S.E.2d 293 (Ga. Ct. App. 1992); State v. Ranson, 511 N.W.2d 97 (Neb. 1994); People v. Whitted, 718 N.Y.S.2d 162 (City Ct. 2000).

${ }_{103}$ United States v. McFadden, 238 F.3d 198 (2d Cir. 2001) (applying New York law).

104 United States v. Bell, 54 F.3d 502 (8th Cir. 1995) (applying lowa law).

ics People v. Allibalogun, 727 N.E.2d 633 (IIl. App. Ct. 2000).

${ }_{106}$ In re Charles C., 90 Cal. Rptr. 2d 430 (Ct. App. 1999); In re J.M., 995 S.W.2d 838 (Tex. App. 1999).

${ }_{107}$ In re Humberto O., 95 Cal. Rptr. 2 d 248 (Ct. App. 2000); State ex rel. R.D., 749 So. 2d 802 (La. Ct. App. 1999).

United States v. Lugo, 170 F.3d 996 (10th Cir. 1999) (applying Utah law); Kearse v. State, 986 S.W.2d 423 (Ark. Ct. App. 1999).

${ }^{109}$ State v. Hehman, 544 P.2d 1257 (Wash. Ct. App. 1976).

110 State v. Thompson, 104 Wash. App. 1008 (Wash. Ct. App. 2001).

"I People v. Pantusco, 484 N.Y.S.2d 321 (App. Div. 1985); State v. Pallone, 613 N.W.2d 568 (Wis. 2000).

${ }^{112}$ State v. Thompson, 536 So. 2d 388 (Fla. Dist. Ct. App. 1989). 
rence ${ }^{114}$ urinating in public; ${ }^{115}$ and possessing a suspended driver's license while operating a bicycle (on reasoning that the document permitted misidentification). ${ }^{116}$

Since Atwater, courts have cited the majority's decision to uphold arrests (and incidental searches) for a litany of minor offenses, again very often based on municipal ordinances ${ }^{117}$ including:

walking in a roadway; ${ }^{118}$ possessing an open container of alcohol in public; ${ }^{119}$ driving with an expired vehicle registration sticker $;{ }^{120}$ making an illegal turn while driving, ${ }^{121}$ jaywalking, ${ }^{122}$ driving a car with a non-working headlight; ${ }^{123}$ driving a car with a hole in the car's license plate ${ }^{124}$ riding a bicycle the wrong direction on a residential street ${ }^{125}$ or without a headlight; ${ }^{126}$ public urination; ${ }^{127}$ driving a bike against traffic; ${ }^{128}$

\footnotetext{
${ }^{113}$ Commonwealth v. Moscat, 731 N.E.2d 544 (Mass. App. Ct. 2000).

114 State v. Greene, 983 P.2d 1190 (Wash. Ct. App. 1999).

115 Commonwealth v. Williams, 568 A.2d 1281 (Pa. Super. Ct. 1990); McConnell v. State, No. 14-99-00887-CR, 2001 WL 8344 (Tex. App. Jan. 4, 2001).

${ }^{116}$ Caraballo v. State, 753 So. 2d 695 (Fla. Dist. Ct. App. 2000). For examples of preAtwater judicial invalidation of warrantless minor offense arrests, as constitutionally unreasonable, see Barnett v. United States, 525 A.2d 197 (D.C. 1987) (jaywalking); Thomas v. State, 614 So. 2d 468 (Fla. 1993) (riding a bicycle without a bell); State v. Carver, 577 N.W.2d 245 (Minn. Ct. App. 1998) (speeding).

117 For a discussion of the significant power of municipal governments to enact laws enforceable by state, local and federal officers, see Wayne A. Logan, The Shadow Criminal Law of Municipal Governance, 62 ОнІо ST. L.J. 1409 (2001).

${ }_{118}$ Collins v. State, No. 14-00-00814-CR, 2001 WL 664644 (Tex. Ct. App. June 14, 2001).

119 People v. Lopez, No. HO24173, 2003 WL 21942954 (Cal. Ct. App. Aug. 14, 2003); State v. Roche, 928 So. 2d 761 (La. Ct. App. 2006).

${ }_{120}$ Nicholson v. State, No. 05-00-01401-CR, 2001 WL 515919 (Tex. Ct. App. May 16, 2001).

${ }_{121}$ People v. Fennell, No. B144396, 2001 WL 1190768 (Cal. Ct. App. Oct. 1, 2001).

122 United States v. Pratt, 355 F.3d 1119 (8th Cir. 2004) (applying Missouri law);

State v. Barros, 48 P.3d 584 (Haw. 2002); State v. Brown, No. 18972, 2001 WL 1657828

(Ohio Ct. App. Dec. 28, 2001).

${ }^{123}$ State v. Wilkenson, 769 N.E.2d 430 (Ohio Ct. Com. Pl. 2001).

${ }_{124}$ People v. Lambert, No. D052435, 2009 WL 1091704 (Cal. Ct. App. 2009).

125 People v. McKay, 41 P.3d 59 (Cal. 2002).

126 Brown v. State, No. 13-05-243-CR, 2006 WL 2025145 (Tex. App., July 20, 2006).

127 State v. Mercante, 836 So. 2d 596 (La. Ct. App. 2002).

128 People v. Bybee, No. B171855, 2004 WL 1689782 (Cal. Ct. App. July 29, 2004).
} 
and violating a city ordinance for remaining in a public park after hours. ${ }^{129}$

At the same time, courts have invoked Atwater to bar civil rights actions based on arrests for very minor offenses, without searches, as condoned in Atwater, ${ }^{130}$ which in conjunction with data showing that most misdemeanor arrests do not result in prosecution, ${ }^{131}$ raises serious question whether police rarely resort to "unnecessary" minor offense arrests.

The judicial and empirical record thus readily contradicts the presumption that afforded constitutional solace to the Atwater majority. In a case decided shortly after Atwater in the 2000-2001 Term, involving a car inventory stemming from an arrest for several minor vehicle-related offenses, Justice O'Connor and the three other Atwater dissenters concurred on

${ }^{129}$ Tanberg v. Sholtis, 401 F.3d 1151 (10th Cir. 2005) (applying New Mexico law); Hudson v. State, No. CACR00-1013, 2001 WL 541069 (Ark. Ct. App. May 23, 2001).

130 See, e.g., Thomas v. City of Peoria, 580 F.3d 633 (7th Cir. 2009) (unpaid parking tickets); Lorenzo v. City of Tampa, 259 Fed. App'x 239 (11th Cir. 2007) (illegally distributing handbills); Williams v. Rodriguez, 509 F.3d 392 (7th Cir. 2007) (double parking vehicle); Tanberg v. Sholtis, 401 F.3d 1151 (10th Cir. 2005) (being in a municipal park after closing); Chortek v. City of Milwaukee, 356 F.3d 740 (7th Cir. 2004) (illegally selling tickets); Lee v. Ferraro, 284 F.3d 1188 (11th Cir. 2002) (noise ordinance); Lowe v. Spears, No. 3:06-0647, 2009 WL 1393860 (S.D. W. Va. May 15, 2009) (parking violation); Revely v. City of Huntington, No. 3:07-0648, 2009 WL 1097972 (S.D. W. Va. Apr. 23, 2009) (failure to stop a car parallel with a stop sign); Hitto v. City of Murphy, No. 4:08cv-221, 2009 WL 801772 (E.D. Tex. Mar. 24, 2009) (running a stop sign while driving a bicycle); Shipp v. Bucher, No. 8:07-cv-440-T-17TBM, 2009 WL 179668 (M.D. Fla. Jan. 26, 2009) (public disposal of lighted material (cigarette)); Wasserman v. Rodacker, No. 06-1005 (RWR), 2007 WL 2071649 (D.D.C. July 18, 2007) (walking dogs without a leash); Sands v. City of New York, No. CV 045275 BMC CLP, 2006 WL 2850613 (E.D.N.Y. Oct. 3, 2006) (littering); Holloman v. City of Myrtle Beach, No. 4:04-1868, 2006 WL 4869353 (D.S.C. June 8, 2006) (following a police car too closely (1.5 lengths)); Bennett v. Booth, No. Civ. A. 3:04-1322, 2005 WL 2211371 (S.D. W. Va. Sept. 9, 2005) (unlawful display of a "Friends of Police" emblem on car).

'31 See Surell Brady, Arrests Without Prosecution and the Fourth Amendment, 59 MD. L. REV. 1, 46 (2000) (discussing data showing that majority of state misdemeanor arrests do not ultimately result in prosecution). Aggregate arrest data (while likely understated, for reasons noted) indicate the high frequency of arrests based on minor offenses. See Sourcebook OF CRIMINAL JuSTICE STATISTICS ONLiNe tbls. 4.1, 4.7 (Ann L. Pastore \& Kathleen Maguire, eds., 2007), http://www.albany.edu/sourcebook/tost_4.html (noting millions of minor offense-based arrests, exclusive of non-DUI traffic violations); K. Babe Howell, Broken Lives from Broken Windows: The Hidden Costs of Aggressive Order-Maintenance Policing, 33 N.Y.U. REv. L. \& Soc. CHANGE 271, 280-90 (2009) (examining huge volume of minor offense arrests in New York City). 
stare decisis grounds, ${ }^{132}$ but expressed "hope" that the majority would reconsider its holding in Atwater "if experience demonstrates 'anything like an epidemic of unnecessary minor-offense arrests." "133 Unfortunately, this reconsideration, based on what Justice Brandeis called the "lessons of experience," has not been forthcoming. ${ }^{134}$ As a result, with probable cause serving as the sine qua non of Fourth Amendment reasonableness, both visible and invisible arrests-and searches-have occurred without meaningful constitutional limit. ${ }^{135}$ This expanded arrest power has major personal consequences for individuals, as noted by Justice O'Connor, and has assumed added significance with recent initiatives to extract and retain DNA samples from all arrestees, not solely from persons convicted of crimes. ${ }^{136}$

Finally, Justice O'Connor's insistence on the need for a constitutional limit, rather than relying on what the majority considered the lack of police incentive to arrest and the "good sense (and, failing that, the political accountability) of most local lawmakers and law-enforcement officials, ${ }^{, 137}$ has been validated by subsequent events. Faith that the political process can curb undue police practices, voiced again by the Court in Herring $v$. United States ${ }^{138}$ has proven unjustified. ${ }^{139}$ Notably, in the wake

${ }_{132}$ Arkansas v. Sullivan, 532 U.S. 769, 772-73 (2001) (applying Arkansas law).

133 Id. at 773 (quoting Atwater v. City of Lago Vista, 532 U.S. 318, 353 (2001)).

134 Burnet v. Coronado Oil \& Gas Co., 285 U.S. 393, 407-08 (1932) (Brandeis, J., dissenting).

${ }^{135}$ The Court's recent decision in Arizona v. Gant, 129 S. Ct. 1710 (2009) holds some promise of mitigating the breadth of search incident to arrest authority, at least relative to auto-related stops. In Gant, the Court held that an auto interior search is justified only when "the arrestee is within reaching distance of the passenger compartment at the time of the search or it is reasonable to believe the vehicle contains evidence of the offense of arrest." Id. at 1723. The Gant majority stated that "[i]n many cases, as when a recent occupant is arrested for a traffic violation, there will be no reasonable basis to believe the vehicle contains relevant evidence." Id. at 1719. The "reasonable basis to believe" standard, however, would appear to be a lesser quantum than probable cause, likely serving to limit the effect of the Court's statement.

${ }_{136}$ See Solomon Moore, F.B.I. and States Vastly Expanding Databases of DNA, N.Y. Times, Apr. 19, 2009, at A1.

${ }^{137}$ Atwater, 532 U.S. at 353 (O'Connor, J., dissenting).

$139129 \mathrm{~S}$. Ct. 695, 704 (2009). The Court's view is strikingly reminiscent of that expressed in Wolf v. Colorado, 338 U.S. 25, 31 (1949), where Justice Frankfurter opined that "the internal discipline of the police, under the eyes of an alert public opinion" would obviate the need for a judicially imposed constitutional limit. However, the view 
of Atwater, Texas itself considered enacting a statutory limit on the warrantless arrest authority of police with regard to minor motor vehicle offenses, emulating the laws in several jurisdictions approvingly cited by the majority. ${ }^{140}$ However, the bill failed to secure gubernatorial approval. ${ }^{141}$ With the strong support of law enforcement groups, Governor Rick Perry stated that "[p]eace officers should retain their existing authority to use their discretion to arrest for a traffic violation."142

Moreover, the targets of such discretionary exercises of police authority will not only resemble self-described soccer moms such as Gail Atwater, who was very nearly relegated to the poor house as a result of her litigation. ${ }^{143}$ Rather, what Justice O'Connor termed "constitutional carte blanche"144 extends to all individuals suspected of committing minor offenses, a domain in which police enjoy maximum latitude to exercise discretionary arrest authority. ${ }^{145}$ In this camp one will surely find the politically disempowered, disproportionately persons of color, whose voices are either muted or not heeded by elected officials, or quite possibly, out-of-state visitors whom the police can target with political impunity. ${ }^{146}$

was gainsaid twelve years later in Mapp v. Ohio, 367 U.S. 643, 654-55 (1961), when the Court felt the need to impose the exclusionary sanction on the states.

${ }^{139}$ Cf. Louis D. Bilionis, Process, the Constitution, and Substantive Criminal Law, 96 MicH. L. REv. 1269, 1329 (1998) (noting "breakdowns at the legislative and the discretionary institutional level that are mutually reinforcing").

${ }_{140}$ Atwater, 532 U.S. at 352 (citing examples and noting that "[i]t is of course easier to devise a minor-offense limitation by statue than to derive one through the Constitution").

141 Michele Deitch, Veto Risks Texans' Civil Rights, Dallas MoRning News, July 1, 2001 , at $5 \mathrm{~J}$

112 Wayne A. Logan, Street Legal: The Court Affords Police Constitutional Carte Blanche, 77 IND. L.J. 419, 448 (2002) (citation omitted).

${ }^{43}$ See Milloy, supra note 13.

144 Atwater, 532 U.S. at 366 (O'Connor, J., dissenting).

145 See, e.g., James Walsh \& Dan Browning, Presumed Guilty Until Proved Innocent, STARTRIBUNE (Minneapolis), July 23, 2000, at 1A (noting significantly higher warrantless arrest rates for African-Americans with regard to a broad array of minor offenses); see also David Cole, Foreword: Discretion and Discrimination Reconsidered: A Response to the New Criminal Justice Scholarship, 87 GEO. L.J. 1059, 1083 (1999) ("The problem with discretionary authority . . . is that discretion permits law enforcement to target those whose complaints are least likely to be heard by the rest of the community.").

${ }_{146}$ Such a prospect was noted by Justice Stevens in Knowles v. Iowa, 525 U.S. 113 (1998), where the Court invalidated a police officer's search incident to issuance of a citation. See Transcript of Oral Argument at 49, Knowles v. Iowa, 525 U.S. 113 (No. 97- 
Justice O'Connor's insistence on a constitutional limit is further justified given the Court's recent decision in Virginia $v$. Moore. ${ }^{147}$ Making ample use of Atwater as precedent, the Moore Court held that state statutory limits on police discretionary arrest authority for minor offenses were immaterial for Fourth Amendment purposes. ${ }^{148}$ In Moore, police arrested a motorist in flagrant defiance of a Virginia law that limited custodial arrests to specified instances, such as when the violator refuses to discontinue the offense. ${ }^{149}$ The arresting officer stated that executing an arrest instead of issuing a citation for driving with a suspended license was his "prerogative." ${ }^{\text {"50 }}$ He thereafter conducted a search and discovered crack cocaine in Moore's vehicle, which ultimately led to Moore's conviction for possession of cocaine with intent to distribute. ${ }^{151}$ Invoking Atwater's "probable cause standard" and re-asserting the absence of any "epidemic" of "horribles" that compels redress, the Moore Court stated:

[A]n arrest based on probable cause serves interests that have long been seen as sufficient to justify the seizure ... . A State is free to prefer one search-and-seizure policy among the range of constitutionally permissible options, but its choice of a more restrictive option does not render the less restrictive ones unreasonable, and hence unconstitutional. ${ }^{152}$

With Moore, the Court thus dashed the lingering hope of direct legislative redress for the exercise of unreasonable discretionary arrest authority of police, using Atwater's substitute of probable cause for reasonableness as constitutional justification. ${ }^{153}$ As Moore and Atwater in tandem make clear, constitu-

7597), 1998 WL 781827 (observing that Iowa police might save the strategy of arresting rather than ticketing "for out-of-state motorists").

128 S. Ct. 1598 (2008).

${ }^{148}$ Id. at 1604-07; see also id. at 1609 (Ginsburg, J., concurring).

149 Id. at 1602.

150 Joint Appendix at 15, Moore, 128 S. Ct. 1598 (2007) (No. 06-1082)

151 Moore, 128 S. Ct. at 1602.

152 Id. at 1606 .

153 See id. at 1604 (noting that "when an officer has probable cause to believe a person committed even a minor crime in his presence, the balancing of private and public interests is not in doubt. . . . The arrest is constitutionally reasonable."); see also id. at 1608 ("When officers have probable cause to believe that a person has committed a crime in their presence, the Fourth Amendment permits them to make an arrest, and to 
tional reasonableness turns solely on probable cause that a substantive law was violated, irrespective of whether a jurisdiction procedurally authorizes (Atwater) or prohibits (Moore) arrest for its violation. As a result, warrantless arrests for minor offenses have continued unabated. ${ }^{154}$

Ultimately, the Atwater majority's understanding of both police motivation and the incidence of minor offense arrests stems from a basic confidence in the equitable use by police of their discretionary authority. As Ronald Dworkin once noted, however, "[d]iscretion, like the hole in a doughnut, does not exist except as an area left open by a surrounding belt of restriction." 155 With Atwater, this "belt," long supported by judicial sensitivity to police abuses of discretionary authority ${ }^{156}$ and decades of research, ${ }^{157}$ has essentially ceased to exist.

search the suspect in order to safeguard evidence and ensure their own safety."). Atwater-decided in 2001-served as the anchor of the Moore Court's reference to the "long line" of cases equating probable cause with constitutional reasonableness, the historical verity of which was justly questioned by Justice Ginsburg in her Moore concurrence. Moore, $128 \mathrm{~S}$. Ct. at 1608-09 (Ginsburg, J., concurring).

${ }^{154}$ In the future, such arrests may not be limited to non-breach-of-the-peace offenses occurring "in the presence" of arresting officers. The Atwater majority expressly disclaimed the need to address whether the accepted common law requirement enjoyed constitutional status, seeing no need to "speculate" on the question, presumably because Turek witnessed Atwater's seatbelt violation. Atwater v. City of Lago Vista, 532 U.S. 318,340 n.11 (2001). However, the majority signaled its view that the requirement is not of Fourth Amendment stature, citing to a prior comment to this effect by Justice White. Id. (quoting Welsh v. Wisconsin, 466 U.S. 740, 756 (1984) (White, J., dissenting)).

150 RONALD DWORKIN, TAKING Rights SERIOUSLY 31 (1977).

${ }_{156}$ Such concern was perhaps most famously evinced by Justice Robert Jackson's assertion that search and seizure authority should not be left only to "the officer engaged in the often competitive enterprise of ferreting out crime." United States v. Johnson, 333 U.S. 10, 14 (1948). For similar acknowledgements in later years see, for example, Coolidge v. New Hampshire, 403 U.S. 443, 449 (1971); Chapman v. United States, 365 U.S. 610, 614 (1961). See also Herbert L. Packer, The Courts, The Police, and the Rest of Us, 57 J. CRIM. L., CRIMINology \& Police SCI. 238, 241 (1966) (observing that the judiciary was "unconvinced that the police regard the rights of the accused as anything but a nuisance and an impediment").

${ }^{157}$ See, e.g., WAYNe R. LAFAVE, ARREST: THE Decision to TAKE a Suspect INTO Custody (Frank J. Remington ed., 1965); see also Allen SteinberG, ThE Transformation of Criminal Justice, Philadelphia 1800-1880, at 180-81 (1989) (quoting a local city judge, alarmed at the increasing resort by police to arrest for minor offenses, who demanded that they cease their "constant habit of arresting parties in order to search them."). 


\section{THE PERILS OF Positivist POLICING}

By equating probable cause with constitutional reasonableness, Justice O'Connor correctly observed, the Atwater majority freed police to invoke minor offenses as bases for arrest, permitting the widespread "pointless indignity" suffered by lawbreakers such as Gail Atwater ${ }^{158}$ and the "grave potential for abuse" associated with unfettered discretionary arrest authority. ${ }^{159}$ The myriad of substantive offenses today codified in state, federal, and local government codes, have become, in the wake of Atwater, tools for the exercise of discretionary police arrest authority. The Court itself has refused to regulate these tools, eschewing imposition of limits on possibly "exorbitant codes"160 for purposes of police enforcement, and rejecting, as Virginia $v$. Moore established, any federal constitutional limiting effect of cognate state procedural limits on police arrest authority. ${ }^{161}$

Because police officers take oaths to enforce the law, the Court's insistence that their arrest authority be based on a suspected violation of positive law should come as no surprise. Indeed, as Justice O'Connor emphasized, governments clearly act within their rights when they legislate pursuant to their police power authority, including malum prohibitum offenses. ${ }^{162}$ However, as she also noted, not all laws should be the same relative to police discretionary arrest authority. This part examines several important consequences of the Atwater majority's decision to make constitutional reasonableness turn on probable cause that an offense, no matter how menial, has occurred.

158 Atwater, 532 U.S. at 371 (O’Connor, J., dissenting).

159 Id. at 372.

160 Whren v. United States, 517 U.S. 806, 818 (1996). See also Safford Unified Sch. Dist. \#1 v. Redding, 129 S. Ct. 2633, 2651 (2009) (Thomas, J., dissenting) (specifying a "basic principle of the Fourth Amendment: that law enforcement officials can enforce with the same vigor all rules and regulations irrespective of the perceived importance of any of those rules") (citing Atwater, 532 U.S. at 347).

${ }^{161}$ See supra notes 147-154 and accompanying text. For discussion of the risks associated with decoupling substantive laws from their accompanying procedural limits, see Wayne A. Logan, Creating a "Hydra in Government": Federal Recourse to State Law in Crime Fighting, 86 B.U. L. REV. 65, 74-75 (2006).

${ }^{162}$ Atwater, 532 U.S. at 371-72 (O'Connor, J., dissenting). 


\section{A. "Law in the Air"}

The Texas law at issue in Atwater, penalizing a motorist's failure to wear a seat belt-resulting in a fine-is representative of countless state, local, and federal laws targeting similar misconduct of a relatively non-serious nature. ${ }^{164}$ In Atwater, only a single law was implicated. Three years later, in Devenpeck v. Alford ${ }^{165}$ the Court made clear that the greater the number of laws potentially at play, the greater the likelihood that an arrest will be deemed constitutionally valid.

In Alford, police arrested an individual because he was believed to be tape recording a traffic stop in violation of state privacy laws. After a determination that Alford's behavior was in actuality not illegal, the charges against him were dismissed. ${ }^{166}$ Thereafter, prosecutors filed new legally actionable charges, based on the arresting officer's subsequent contention that probable cause existed at the time to support arrest for other offenses not initially identified by the arresting officer (e.g., impersonating a police officer). ${ }^{167}$ The Court unanimously held the new grounds of arrest were constitutionally reasonable, even though not "closely related" to the alleged misconduct serving as the initial basis for arrest. ${ }^{168}$ Probable cause that a legal violation occurred, "drawn from the facts known to the arresting officer," even if based on ex post legal extrapolations of the entire legal code, can thus constitutionally validate an arrest. ${ }^{169}$ An officer's "subjective reason for making the arrest need not be the criminal offense as to which the known facts provide probable cause." $^{170}$ So long as probable cause exists that some offense occurred, an arrest is constitutionally reasonable, even if the legal

\footnotetext{
163 With a hat tip of course to Justice Cardozo who alternatively argued that "negligence in the air," absent proof of violation of a legal norm, will not suffice to create tort liability. See Palsgraf v. Long Island R.R., 162 N.E. 99, 99 (N.Y. 1928) (Cardozo, J.).

164 See supra notes 101-130 and accompanying text.

165543 U.S. 146 (2004).

166 Id. at 149-51.

167 Id. at 149-50.

168 Id. at 155-56.

169 Id. at 152. The court added, "[T] hose are lawfully arrested whom the facts known to the arresting officers give probable cause to arrest." Id. at 155.

I70. at 153 .
} 
basis is not specified, or indeed, if the basis initially specified turns out to lack legal justification.

Atwater and Alford, ${ }^{171}$ together with Moore's disregard of procedural limits on police arrest authority, have empowered police to use any law, at any time, and any place, ${ }^{172}$ to justify arrests, and hence searches. ${ }^{173}$ Given the heavily regulated nature of modern society, especially relative to motor vehicles, ${ }^{174}$

171 For examples of recent decisions expressly combining Alford and Atwater, see Brown v. Fisher, 251 Fed. App'x. 527 (10th Cir. 2007) (applying Kansas law); Apodca v. City of Albuquerque, 443 F.3d 1286 (10th Cir. 2006) (applying New Mexico law); Tatum v. City of San Francisco, 441 F.3d 1090 (9th Cir. 2006) (applying California law); United States v. McNeill, 484 F.3d 301 (4th Cir. 2007) (applying Maryland law). For examples of earlier courts deploying Atwater to reach results later also authorized by Alford, see Williams v. Jaglowski, 269 F.3d 778 (7th Cir. 2001) (applying Illinois law); People v. Bybee, No. B171855, 2004 WL 1689782 (Cal. Ct. App. July 29, 2004).

It warrants mention that Alford potentially builds on language in United States $v$. Leon, 468 U.S. 897 (1984), which suggested that information possessed by other officers can augment and rehabilitate infirm probable cause assessments by arresting officers. See id. at $923 \mathrm{n} .24$ ('References to 'officer' throughout this opinion should not be read too narrowly. It is necessary to consider the objective reasonableness, not only of the officers who eventually executed a warrant, but also of the officers who originally obtained it or who provided information material to the probable-cause determination."); see also Whitely v. Warden, 401 U.S. 560 (1971) (recognizing the "collective knowledge" doctrine).

${ }_{172}$ See, e.g., United States v. Turner, 553 F.3d 1337, 1345-46 (10 ${ }^{\text {th }}$ Cir. 2009) (applying Colorado law and, citing Atwater and Moore, holding that jurisdictional geographic limits on police arrest authority have no bearing on constitutionality of arrest).

173 The Court's recent decision in Arizona v. Gant, 129 S. Ct. 1710 (2009), presents an interesting question vis-à-vis Alford. As noted earlier, the Court imposed new limits on police search incident to arrest authority, deeming an automobile search justified only when "the arrestee is within reaching distance of the passenger compartment at the time of the search or it is reasonable to believe the vehicle contains evidence of the offense of arrest." Id. at 1723 (emphasis added). Alford's bearing on the latter consideration remains to be seen when, for example, the initial basis for arrest leads an officer to reasonably believe the car contains relevant evidence, but the substantive legal basis for the arrest itself (as in Alford) is later deemed invalid.

${ }_{174}$ See Wayne R. LaFave, The "Routine Traffic Stop" from Start to Finish: Too Much "Routine," Not Enough Fourth Amendment, 102 MICH. L. REV. 1843, 1853 (2004) (noting that "very few drivers can traverse any appreciable distance without violating some traffic regulation"). Atwater's application in the auto context, as Professor Dave Moran has astutely observed, can function to moot the Court's case law limiting police roadblocks. See David A. Moran, The New Fourth Amendment Vehicle Doctrine: Stop and Search Any Car at Any Time, 47 VILL. L. REV. 815, 832 (2002) ("If an officer may stop any car she observes committing any traffic or equipment violation, arrest the motorist and search the car, there is no need to set up roadblocks. Indeed, it would obviously be much more efficient and productive for the police to single out 'suspicious' motorists, [and] stop and arrest them for trivial violations ...."). 
the power is manifestly far greater than that enjoyed by framing era police. ${ }^{175}$

\section{B. "Could have Arrested" Authority}

Atwater's positivist orientation has encouraged and fortified another feature of modern street-level policing : the "could have arrested" authority. The question of whether an actual arrest is necessary to justify an incidental search would appear to have been settled by several of the Court's prior decisions. In particular, in Cupp v. Murphy ${ }^{176}$ the Court stated:

Where there is no formal arrest, as in the case before us, a person might well be less hostile to the police and less likely to take conspicuous, immediate steps to destroy incriminating evidence on his person. Since he knows he is going to be released, he might likely be instead to be concerned with diverting attention away from himself. ${ }^{177}$

Similarly, the Court's unanimous 1998 decision in Knowles $v$. Iowa, prohibiting police from conducting searches incident to issuance of a citation, was clearly predicated on the occurrence of an actual arrest. ${ }^{178}$ Even though Iowa law expressly authorized arrest (as in Atwater) for a speeding offense, the fact that the officer did not arrest Knowles-but rather merely issued a citation-rendered the ensuing search unconstitutional. ${ }^{179}$ Tak-

175 As Professor Tom Davies has convincingly shown, during the framing era the ex parte warrantless arrest authority of police, such as it existed, was very limited. Thomas Y. Davies, Recovering the Original Fourth Amendment, 98 MicH. L. REV. 547 (1999). The limited authority stemmed inter alia from the requirement that an offense have been committed "in fact." Id. at 651. "[The] common law required that arrest or search warrants had to be based on an allegation of an offense or theft 'in fact' as well as 'probable cause of suspicion' as to a particular person to be arrested or place to be searched." Id. at 703; see also Davies, supra note 58, at 301-26.

176412 U.S. 291 (1973).

${ }^{177} I d$. at 296. The Court did, however, allow admission of incriminating evidence found pursuant to what it termed a "very limited search," one "necessary to preserve the highly evanescent evidence [police] found under [the suspect's] fingernails." Id.

178 525 U.S. 113 (1998).

${ }^{179}$ Id. at 118-19. Indeed, the Iowa Supreme Court's contrary decision below expressly relied on the "could have" approach, based on its prior decision in State v. Doran, 563 N.W.2d 620 (Iowa 1997). According to Doran, search-incident authority: 
en together, Cupp and Knowles, along with the Court's several landmark search-incident cases, in which arrests indisputably occurred, ${ }^{180}$ make clear that an actual arrest must occur before a search is authorized-not merely that probable cause to arrest existed. ${ }^{181}$

[I]s dependent upon facts that provide a legal basis for making a custodial arrest rather than the act of arrest itself ....

-...

... We have adopted an objective or "could" assessment of the arresting officer's conduct in making the arrest "so long as the officer is legally permitted and objectively authorized to do so, an arrest is constitutional."

$\ldots$

... If the officer is legally permitted and objectively authorized to make the arrest, he is, for that reason alone, also authorized to make the search.

Id. at 622-23 (citation omitted). Expressing a sentiment strikingly prescient of the ramifications of Atwater itself, Justice Neuman wrote in dissent:

It is, indeed, expedient ... to enhance the power of police officers. . . . But the sweep of today's opinion will also sacrifice the personal privacy of "soccer moms" driving a little too fast to the ball field, senior citizens motoring along without a taillight, and otherwise "good kids" who fail to dim their high beams swiftly enough. All will be subject to search at the whim of the officer, not because they will be taken into custody, but because they could have been.

Id. at 624 (Neuman, J., dissenting).

${ }_{180}$ See, e.g., New York v. Belton, 453 U.S. 454 (1981); United States v. Robinson, 414 U.S. 218 (1973); Chimel v. California, 395 U.S. 752 (1969). Furthermore, a basic assumption of search-incident doctrine is that a search is justified because of the incidence of an actual arrest. See Belton, 453 U.S. at 461 (stating that a "container may, of course, be searched whether it is open or closed, since the justification for the search is not that the arrestee has no privacy interest in the container, but that the lawful custodial arrest justifies the infringement of any privacy interest the arrestee may have"); Robinson, 414 U.S. at 235 (stating that an "arrest of a suspect . . is a reasonable intrusion under the Fourth Amendment," and "that intrusion being lawful, a search incident to the arrest requires no additional justification").

${ }_{181}$ As the Wisconsin Supreme Court has observed, the Court's decision in United States v. Robinson:

[M]ade clear that it is the fact of the lawful arrest which establishes the authority to undertake an extensive search for weapons and evidence of a crime. The actual making of a formal arrest, as opposed to the mere existence of grounds for doing so, is considered to be a significant event. The lawful arrest is not a mere formality, and without an arrest there is no justification for a full search incident to an arrest.

State v. Swanson, 475 N.W.2d 148, 154 (Wis. 1991) (citation omitted). See also State v. Pallone, 613 N.W.2d 568, 577 (Wis. 2000) ("For the search incident to arrest exception to apply, there must be an arrest ... . The requirement of an arrest is a 'bright line rule") (quoting Knowles, 525 U.S. at 113,117-18 (1998)); HARVEY CORTLAND VORHEES, THE LAW OF ARREST IN CIVIL AND CRIMINAL ACTIONS \& 209, at 173 (2d ed. 1915) (stating "an 
Nevertheless, the case law contains numerous instances of state and lower federal courts endorsing the "could have arrested" doctrine. Before Atwater, this tendency was common enough, ${ }^{182}$ both raising constitutional concern and stunting development of the law of arrest. ${ }^{183}$

Predictably, Atwater, with its probable cause-based constitutional standard, has fostered proliferation of the view, ${ }^{184}$ even though probable cause is neither susceptible of precise understanding ${ }^{185}$ nor hard to satisfy. ${ }^{186}$ Courts have also used the ra-

officer has no right to search a person and seize anything upon him unless he has first arrested him").

${ }_{182}$ See, e.g., United States v. Ricard, 563 F.2d 45, 49 (2d Cir. 1977) (“[T] he fact that [the officerl had cause to arrest appellant for speeding, even if he initially determined not to do so, was a sufficient predicate for a full search."); Commonwealth v. Mantinez, 692 N.E.2d 92, 96 (Mass. Ct. App. 1998) ("Probable cause for an arrest, even if not acted upon by a formal arrest, brings with it the 'search incident to arrest' exception to the warrant requirement for a search.") (citing Commonwealth v. Brillante, 399 Mass. 152, 155 n. 6 (1987)); State v. Roach, 452 N.W.2d 262, 266 (Neb. 1990) ("It is not necessary that an actual formal arrest occur before a search is undertaken, as long as probable cause for arrest does exist"); State v. Greenslit, 559 A.2d 672, 674 (Vt. 1989) (“II]t is the existence of probable cause for the arrest which brings the search within constitutional limits, not merely the act of taking the individual into custody.").

189 This underdevelopment stands in stark contrast to the rich jurisprudence concerning when a suspect is in "custody" for Miranda purposes and when a "de facto" arrest occurs (as opposed to a Terry stop) requiring probable cause. See Thomas K. Clancy, The Supreme Court's Search for a Definition of a Seizure: What is a "Seizure" of a Person Within the Meaning of the Fourth Amendment?, 27 AM. CRIM. L. REV. 619 (1999) (discussing distinctions between de facto arrests and stops); Anne Bowen Poulin, The Fourth Amendment: Elusive Standards; Elusive Review, 67 CHI.-KENT L. REv. 127, 138 n.76 (1991) (noting that "post-Miranda cases dwell on the definitions of custody and interrogation"). As a result, what Richard Uviller has called the "magical moment of arrest" has largely been mooted, disabling development of an important aspect of Fourth Amendment law. See H. Richard Uviller, VirTual Justice: The Flawed Prosecution of Crime in America 28 (1996). See also Wayne R. LAFAVE, 3 SEARCh AND SEIZURE: A TREATISE ON THE FOURTH AMENDMENT \& 5.1, at 2 (4th ed. 2004) (noting that "[i]t is often important to determine whether or not the police have made an arrest and, if they have, precisely when the arrest occurred").

${ }_{184}$ See, e.g., United States v. Pratt, 355 F.3d 1119, 1122-24 (8th Cir. 2004) (applying Missouri law and citing Atwater in support); People v. Branner, 92 Cal. Rptr. 3d 272, 276 (Cal. Ct. App. 2009) (citing Atwater in support).

${ }_{185}$ See Illinois v. Gates, 462 U.S. 213, 232 (1983) (noting that probable cause is a "fluid" concept "not readily . . . reduced to a neat set of legal rules"); Ornelas v. United States, 517 U.S. 690, 695 (1996) (noting difficulty in articulating "precisely what Iprobable causel means"). In addition, of late the Court has haphazardly conflated probable cause with ostensibly lesser standards relating to reasonableness. See, e.g., Maryland v. Pringle, 540 U.S. 366, 371 (2003) (stating that " $t$ the substance of all the definitions of probable cause is a reasonable ground for belief of guilt"). 
tionale to justify otherwise impermissible delays in auto stops ${ }^{187}$ because under Atwater police could have executed an arrest. ${ }^{188}$ The persuasive appeal of the doctrine is so potent as to redeem searches when police have issued a citation before undertaking a search, an outcome contrary to Knowles $v$. Iowa, ${ }^{189}$ again predicated on the argument that because police could have arrested they were entitled to search. ${ }^{190}$

The upshot of the foregoing is that police, with probable cause to believe that a minor offense has occurred, yet having a mere hunch of greater wrongdoing, can argue with constitutional justification that they could have arrested an individual, even if they do not. They can then lawfully conduct a body (or auto) search, and, if nothing more incriminating is discovered, engage in the time-honored practice of setting the individual free with a citation or warning. ${ }^{191}$ Alternatively, in the absence of even a hunch of greater wrongdoing, police can arrest and search, and discover a basis justifying pursuit of a more serious prosecution, which itself too often pressures courts to indulgently assess already lax probable cause standards. ${ }^{192}$ Finally, police can poten-

${ }^{186}$ See, e.g., Gates, 462 U.S. at 238 (describing the standard as tantamount to a "fair probability"); Valdez v. McPheters, 172 F.3d 1220, 1227 n.5 (10th Cir. 1999) (noting that "probable cause itself is a relatively low threshold of proof"). As Bill Stuntz recognized several years before Atwater was decided, "In a world where trivial crimes stay on the books, or one where routine traffic offenses count as crimes, the requirement of probable cause to arrest may mean almost nothing." William J. Stuntz, The Uneasy Relationship Between Criminal Procedure and Criminal Justice, 107 YALE L.J. 1, 7 (1997).

${ }^{187}$ See United States v. Sharpe, 470 U.S 675, 686 (1985) (requiring that police "diligently pursue[ a means of investigation that [is] likely to confirm or dispel their suspicions quickly").

188 See, e.g., United States v. Carpenter, 406 F.3d 915, 916 (7th Cir. 2005) (applying federal law); Wilkes v. State, 774 A.2d 420, 438 (Md. 2001).

525 U.S. 113 (1998).

${ }^{130}$ Carpenter, 406 F.3d at 916-17.

191 See LAFAVE, supra note 157, at 186-88, 484-85 (noting widespread police "arrest and release" in the $1950 \mathrm{~s}$ and 1960s); Jerome Hall, The Law of Arrest in Relation to Contemporary Social Problems, 3 U. CHI. L. REV. 345, 359-62 (1936) (describing same practice during the first decades of the twentieth century).

${ }_{192}$ See State v. Overby, 590 N.W.2d 703, 708 (N.D. 1999) (Vande Walle, C.J., concurring) (expressing concern that "with the expectation or hope that the search will produce such irrefutable evidence of the commission of a crime that a lack of probable cause to arrest prior to the search will be overlooked or such suspicion as did exist will be viewed more favorably in light of the evidence discovered in the search if, in fact, there is evidence discovered"); JEROME H. SKOLNICK, JUSTICE WITHOUT TRIAL 221 (1975) ("The illegality of a search is likely to be tempered--even in the eyes of the judiciary-by the 
tially use Atwater to threaten arrest for a minor offense, presuming probable cause exists to support such an arrest, in order to secure "voluntary" consent to search, ${ }^{193}$ which depending on the outcome of the search, can result in a more serious prosecution, or immediate freedom for the individual. Under any of these scenarios, Justice O'Connor's prediction in Atwater of a "grave potential for abuse" comes to fruition. ${ }^{194}$

\section{C. "Mistakes" of Law}

Atwater's apotheosis of probable cause and substantive laws has also served to heighten the importance of the latitude afforded police in their misapprehension of the laws they invoke to justify arrests. Historically, of course, lack of knowledge or misunderstanding of criminal laws has been rejected as a basis for citizens to avoid criminal liability. ${ }^{195}$ With respect to police, courts typically reject government arguments that an officer's misapprehension of an invoked law can justify a seizure, on the view that enforcement of a non-existent legal standard itself is not objectively reasonable. ${ }^{196}$ To find such a seizure justified would be to countenance a "failure to understand the law by the very person charged with enforcing it. ${ }^{1197}$ Doing so, furthermore, "would remove the incentive for police to make certain that they

discovery of incriminating evidence on the suspect.”; Akhil Reed Amar, Fourth Amendment First Principles, 107 HARV. L. REV. 757, 799 (1994) (“Judges do not like excluding bloody knives, so they distort doctrine, claiming that the Fourth Amendment was not really violated.").

${ }_{193}$ See 3 LAFAVE, supra note 183 , at $\$ 8.2(\mathrm{c})$.

194 Atwater v. City of Lago Vista, 532 U.S. 318, 372 (2001) (O'Connor, J., dissenting).

${ }^{195}$ See Oliver W. Holmes, The Common LaW 41 (Belknapp Press, 1963):

It is no doubt true that there are many cases in which the criminal could not have known that he was breaking the law, but to admit [legal mistakes] as an excuse at all would be to encourage ignorance where the law-maker has determined to make men know and obey, and justice to the individual is rightly outweighed by the larger interests on the other side of the scales.

For competing views surveying exceptions to the precept in modern case law, see Sharon L. Davies, The Jurisprudence of Willfulness: An Evolving Theory of Excusable Ignorance, 48 DUKE L.J. 341 (1998) (focusing on crimes that require willfulness mens rea); Dan M. Kahan, Ignorance of the Law Is an Excuse-But Only for the Virtuous, 96 MICH. L. REV. 127 (1997) (focusing on malum prohibitum crimes).

${ }^{196} 4$ LAFAVE, supra note 183 , at $\$ 9.5$ (citing cases).

${ }^{197}$ United States v. Tibbetts, 396 F.3d 1132, 1138 (10th Cir. 2005). 
properly understand the law that they are entrusted to enforce and obey." 198

This core understanding, however, has been eroded in recent years. Even though the law-fact distinction is not always clear-cut, ${ }^{199}$ police are forgiven reasonable mistakes of fact, on which probable cause is based. ${ }^{200}$ Moreover, legal standards themselves often admit of substantial interpretive flexibility. For instance, whether a car is operated on the streets in "good mechanical condition" is a legally and factually loaded determination made by officers-a determination in which they enjoy considerable legal latitude. ${ }^{201}$

In some courts, however, the line-drawing enterprise itself is of no moment. In the Eighth Circuit, for instance, officers are forgiven mistakes of law and fact alike. There, if an officer seizes an individual based on a mistaken understanding of the law she is enforcing, "the legal determination of whether probable cause or reasonable suspicion existed for the stop is judged by whether the mistake of law was an 'objectively reasonable one." ${ }^{202}$ The Eighth Circuit's stance is shared by several states,

United States v. Lopez-Soto, 205 F.3d 1101, 1106 (9th Cir. 2000). See also People v. Teresinski, 605 P.2d 874, 877 (Cal. 1980) (asserting that a contrary rule "would provide a strong incentive to police officers to remain ignorant of the language of the laws and of the teachings of judicial decisions whose principal function frequently is to construe such laws and to chart the proper limits of police conduct.").

See generally 6 LAFAVE, supra note 183, at $\$ 11.7(\mathrm{c})$.

${ }^{200}$ See, e.g., United States v. Booker, 496 F.3d 717 (D.C. Cir. 2007); United States v. Jenkins, 452 F.3d 207 (2d Cir. 2006) (applying New York law); United States v. FloresSandoval, 366 F.3d 961 (8th Cir. 2004) (applying U.S. law). See also Saucier v. Katz, 533 U.S 194, 206 (2001) (“Officers can have reasonable, but mistaken, beliefs as to the facts establishing the existence of probable cause . . . .); Illinois v. Rodriguez, 497 U.S. 177, 185-86 (1990) (noting that factual determinations made by police need not "always be correct," but they always must be "reasonable"); Maryland v. Garrison, 480 U.S. 79, 87 (1987) ("[T]he Court has also recognized the need to allow some latitude for honest [factuall mistakes that are made by officers in the dangerous and difficult process of making arrests and executing search warrants.").

${ }^{201}$ See State v. Beauregard, 820 A.2d 183, 183 (Vt. 2003). See also, e.g., United States v. Valdez, 147 Fed. App'x. 591, 594 (6th Cir. 2005) (construing Tennessee law providing that a vehicle "shall not follow another vehicle more closely than is reasonable and prudent").

${ }^{202}$ United States v. Washington, 455 F.3d 824, 827 (8th Cir. 2006) (citation omitted); see also United States v. Smart, 393 F.3d 767, 770 (8th Cir. 2005) (“[I]n our circuit, the distinction between a mistake of law and a mistake of fact is irrelevant to the fourth amendment inquiry. ... [I]n mistake cases the question is simply whether the mistake, whether of law or fact, was an objectively reasonable one."). 
which also forgive objectively reasonable mistakes of law by police, that is, unlawful but not unreasonable arrests. ${ }^{203}$ Georgia goes even further, asking whether officers acted in good faith:

If the officer acting in good faith believes that an unlawful act has been committed, his actions are not rendered improper by a later legal determination that the defendant's actions were not a crime according to a technical legal definition or distinction determined to exist in the penal statute. It is not the officer's function to determine on the spot such matters as . . . the legal niceties in definition of a certain crime, for these are matters for the courts. ${ }^{204}$

Meanwhile, other courts have signaled their generosity in motions to suppress by emphasizing that officers are not to be held to the standard of a prospective lawyer "taking the bar exam," ${ }^{205}$ and do not need to carry a "Decennial Digest" on the job. $^{206}$ As the Ninth Circuit has observed, an officer need not "have a precise appreciation of the niceties of the law. If the facts are sufficient to lead an officer to reasonably believe that there was a violation, that will suffice, even if the officer is not certain about exactly what it takes to constitute a violation. ${ }^{207}$

Thus, unlike Alford, where a legal mistake was forgiven because there existed unspecified alternative legal bases to justify the arrest, in the cases just noted no valid legal basis existed to support Fourth Amendment seizures. ${ }^{208}$ Whether the Court's

${ }^{203}$ See, e.g., Harrison v. State, 800 So. 2d 1134, $1138-39$ (Miss. 2001); State v. Greer, 683 N.E.2d 82, 86 (Ohio Ct. App. 1996).

${ }_{204}$ McConnell v. State, 374 S.E.2d 111, 113 (Ga. Ct. App. 1988). McConnell's focus on subjective good faith would appear to be on weak footing after Whren; to date, however, Georgia courts seemingly have not deviated from the position. See, e.g., Dixon v. State, 609 S.E.2d 148, 150-51 (Ga. Ct. App. 2005). But see Cash v. State, 593 N.E.2d 1267, 1269 (Ind. Ct. App. 1992) (holding that "simple good faith on the part of the arresting officer is not enough. If it were, 'the protection of the Fourth Amendment would evaporate." (quoting Terry v. Ohio, 392 U.S. 1, 21-22 (1968))).

United States v. Wallace, 213 F.3d 1216, 1220 (9th Cir. 2000).

${ }^{206}$ Kelley v. Myler, 149 F.3d 641, 647 (7th Cir. 1998) (quoting Bodzin v. City of Dallas, 768 F.2d 722, 725 (5th Cir. 1985)).

${ }_{207}$ United States v. Mariscal, 285 F.3d 1127, 1130 (9th Cir. 2002).

${ }^{208}$ What the tendency means for civil rights actions sounding in false arrest and the right of citizens to resist unlawful arrests remains to be seen. See, e.g., State v. Lindsay, 388 So. 2d 781, 782 (La. 1980) ("It is a long-established principle in Louisiana law that a citizen has the right to resist an unlawful arrest."); Riffe v. Armstrong, 477 S.E.2d 535, 
recent decision in Herring $v$. United States ${ }^{209}$ making application of the exclusionary rule depend upon "deliberate" and "culpable" police errors, ${ }^{210}$ will invigorate the tendency toward forgiving reasonable police mistakes remains to be seen. ${ }^{211}$ There is no mistaking, however, that the indulgence undercuts vagueness doctrine, with its foremost concern over arbitrary police enforcement, ${ }^{212}$ and qualifies as a highly troubling development in a society that prides itself on its dedication to the rule of $\operatorname{law}^{213}$ and refuses to forgive similar citizen misunderstandings. ${ }^{214}$ Not only do police now wield the power to act as de facto legislators, based on their discretionary authority to invoke (or nor invoke) extant laws, as Bill Stuntz has noted. ${ }^{215}$ They also have the concomitant power to detain individuals for behavior never even legislatively proscribed.

549 (W. Va. 1996) (noting that false arrest claim must be supported by proof of no legal authority to arrest).

209 129 S. Ct. 695 (2009).

${ }^{210}$ See id. at 702 ("To trigger the exclusionary rule, police conduct must be sufficiently deliberate that exclusion can meaningfully deter it, and sufficiently culpable that such deterrence is worth the price paid by the justice system.").

${ }^{211}$ Of course, attenuation doctrine further dilutes police incentive to master the substance of the laws they are expected to enforce. For instance, if voluntary consent to search is secured, such consent can cure a legally invalid stop or arrest, barring application of the exclusionary rule and allowing admission of any evidence or contraband obtained by the search. See Brown v. Illinois, 422 U.S. 590, 603-04 (1975).

${ }_{212}$ See, e.g., Kolender v. Lawson, 461 U.S. 352, 360-61 (1983). On this connection more generally see Tracey Maclin, What Can Fourth Amendment Doctrine Learn from Vagueness Doctrine?, 3 U. PA. J. ConST. L. 398 (2001).

Importantly, in light of the judicial tendency to forgive police legal mistakes, legislative efforts to codify more detailed laws in order to limit police discretion and guard against successful vagueness challenges can have the opposite effect of facilitating indulgence of police mistakes of law. This is because the more intricate laws become, the greater the latitude police will be afforded for their legal mistakes. Cf. Kim Forde-Mazrui, Ruling Out the Rule of Law, 60 VAND. L. REV. 1497, 1525-26 (2007) (noting that efforts to make laws more specific have not appreciably lessened the discretionary authority of police).

${ }^{213}$ See generally Ronald A. Cass, The Rule of Law in America (2001). Cf. THE DECLARATION OF INDEPENDENCE para. 21 (U.S. 1776) (condemning use by British Crown of "pretended offences" to harass colonists); Franz KAFKa, THE TRIAL 3 (Willa Muir \& Edwin Muir trans., Random House 1956) (1925) ("Someone must have traduced Joseph $\mathrm{K}$, for without having done anything wrong he was arrested one fine morning.").

${ }_{214}$ See United States v. Chanthasouxat, 342 F.3d 1271, 1280 (11th Cir. 2003) (recognizing "the fundamental unfairness of holding citizens to "the traditional rule that ignorance of the law is no excuse,' while allowing those 'entrusted to enforce' the law to be ignorant of it.") (citations omitted).

${ }_{215}$ William J. Stuntz, Substance, Process, and the Civil-Criminal Line, $7 \mathrm{~J}$. CONTEMP. LEGAL ISSUES 1, 24 (1996). 
CONCLUSION

Justice O'Connor's dissent in Atwater $v$. City of Lago Vista is notable both for its steadfast fidelity to Fourth Amendment reasonableness and its astute recognition of the personal and jurisprudential consequences of its abandonment. Wise at its time of issuance, moreover, the dissent has proved prescient. Rather than being merely "speculative," the "dearth of horribles" posited by the Atwater majority was and remains an empirical reality, predictably inspiring other troublesome practices, as outlined above. Stepping back, one can only hope that Justice O'Connor's dissent, like other great dissents, "may salvage for tomorrow the principle that was sacrificed or forgotten today."

216 William O. Douglas, The Dissent: A Safeguard of Democracy, 32 JUDICATURE 104, 107 (1948). See also Charles Evan Hughes, The Supreme Court of The United STATES 68 (1928) ("A dissent in a court of last resort is an appeal to the brooding spirit of the law, to the intelligence of a future day, when a later decision may possibly correct the error into which the dissenting judge believes the court to have been betrayed."). 
